\title{
全芳香族ポリイミドからの高強度・高弾性率繊維
}

\author{
東レ株式会社繊維研究所＼cjkstart神田拓馬・松田敏和・坂本正典
}

\section{HIGH TENACITY AND HIGH MODULUS FIBERS FROM WHOLLY AROMATIC POLYIMIDES}

\author{
By Takuma Jinda, Toshikazu Matsuda and Masanori Sakamoto
}

(Toray Industries, Inc. Fiber and Textile Research Labs. Sonoyama, Otsu 520)

\begin{abstract}
Poly(amic-acids) were synthesized from pyromellitic dianhydride (PMDA) and aromatic diamines, of which the resultant $\mathrm{C}-\mathrm{N}$ bonds are coaxial and oppositely directed (rigid diamines), using $\mathrm{N}$ methylpyrrolidone as polymerization solvent. Random copolymers composed of rigid diamine, PMDA and 3,3',4,4'-diphenylethertetracarboxylic dianhydride (DTDA) were also synthesized. These poly(amic-acids) were partially imidized by adding an appropriate amount of acetic anhydride (15 $\sim 30$ mole\% based on amic-acid unit) into their solutions and then wet-spun, since it was found that partially imidized polymer solutions gave more transparent and void-free coagulated fibers than poly(amic-acid) solutions as polymerized. These fibers were then chemically converted to polyimides by immersing them in an acetic anhydride-pyridine mixture and heat-drawn.

Relatively lower crystalline polyimides such as polypyromellitimides of aromatic diamines bearing chlorine substituent on the nuclei or random copolyimides had better drawability and gave fibers having higher tensile strength than higher crystalline polymers. For example, poly[2,2'dichloro-4,4'biphenylene/p-phenylene (70/30) pyromellitimide] gave a fiber having tenacity $(T)$ $16.3 \mathrm{~g} / \mathrm{d}$, elongation $(E) 2.0 \%$ and initial modulus $\left(M_{\mathrm{i}}\right) 960 \mathrm{~g} / \mathrm{d}$. Another random copolymer composed of benzidine/PMDA/DTDA $(100 / 40 / 60)$ yielded a fiber with the following tensile properties: $T 19.7 \mathrm{~g} / \mathrm{d}, E 1.7 \%$ and $M_{\mathrm{i}} 1310 \mathrm{~g} / \mathrm{d}$.
\end{abstract}

(Received May 15, 1984)

\section{1. 猪}

全芳香族ポリイミドは有機ポリマーの中で最高級の耐 熱性を有しており，その特徵を生加して以前加らフィル ムなどの成型物で実用化されているが，ポリマー構造に よっては耐熱性以外の特性も期待することができる。す なわち， pーフェニレンジアミンのような，銧伸長結合 が同軸で逆向さに伸びている，いわ妕る剛直性の芳香族 ジアンと無水ピロメリト酸(PMDA)からなるポリイ ミドはポリマー鎖が棒状であり，高強度・高弾性率緉維 素材上しての问能性をむっている。にも加加らず，乙 の種の研究はり連の研究者によってわずか比行なわ机て いるにすきない尚。かかるポリイミドは一旦つくって しまうとそれを溶加す溶剂がないので，前駆重合体であ るポリアミト酸の段階で湿式紡糸し，ついで熱水延伸後，
熱睘化するととによってポリイミド䄉維が得られている。 このような製系法では，対称性のよい，したがって結晶 性の高いポリイミドは高弹性率織維にはなっても, 高強 度にはならないだらうと予測されたが，事実，そのとお りであり，たとえば，比較的高強度の得られたポリ（4, 4'ービフェニレンピロメリトイミド)でも $6.9 \mathrm{~g} / \mathrm{d}$ にすぎ ない。とのととはアラミド系の高強度・高弾性率織維の 製法をふりかえってみ机ば理解しやすい。すなわ方，高 結晶性のポリ（ $p$ ーフェニレンテレフタルアミド加は， 現在の Kevlar ${ }^{\circledR}$ の製法である，ポリマー濃度約 $20 \%$ の 光学異方性硫酸溶液の乾湿式紡系によってしか， $20 \mathrm{~g} /$ $\mathrm{d}$ 以上の高強度䋐維は得られない。等方性溶液の湿式紡 系ついで熱延伸という，従来からの製系法では，構造の 対称性を乱し，結晶性をある程度低下さ世延伸性を向上 させたポリマーを用いるてとによって始めて高強度瀻維 
がつくられる。

筆者らは全芳香族ポリイミド栗の高強度・高弹性率䋐 維を目標に，剛植性ジアミンとPMDAからなるポリマ

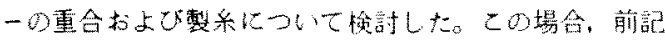
の連の研究者が非核置換の本モポリマーしか取报って いないのに対し，䔔度に結罚性を低下させて延伸性の向 上を図る心く、単位長の珙なるジアミンのランダム共重 合、ジアミン成分への核塩素置換基の導入南るいは泪者 の併用などの手段を用いた。さらに，高生能繊維の得方

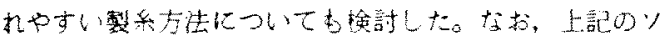
連の研觉者は，屈曲した基古すつが，とりうる市体配筧

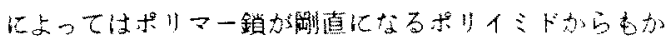

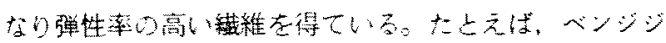
ン上3３３４４４'-ジフェニルエーテルテトラカルボン酸二 無水物(DTDA)古るいは3３，4，4'-ベンゾフェノンテ トラカルボン酸二器水物(BTDA)からなる戊りイミド がそ机でるが。我々はこれらの木モポリマーの他に， PMDAを第三成分として添加したランダム共重合体に かても合わせて検討した。そして，得られた䋐維の引 張特性，䊅晶性，動的粘弾性な゙゙方測定した。

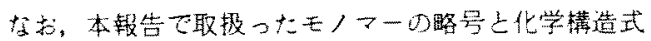
を以下に記す。
$P$
$\mathrm{H}_{2} \mathrm{~N}-\mathrm{O}-\mathrm{NH}_{2}$
Cl.
$\begin{array}{ll}\mathrm{Cl}-\mathrm{P} & : \mathrm{H}_{2} \mathrm{~N}-\mathrm{O}-\mathrm{NH}_{2} \\ \mathrm{Bz} & : \mathrm{H}_{2} \mathrm{~N}-\mathrm{O}-\mathrm{O}-\mathrm{NH}_{2}\end{array}$
$\mathrm{Cl}-\mathrm{Bz} \quad: \mathrm{H}_{2} \mathrm{~N}-\mathrm{O}-\mathrm{O}-\mathrm{NH}_{2}$
$\mathrm{Di}-\mathrm{Cl}-\mathrm{Bz}: \mathrm{H}_{2} \mathrm{~N}-\mathrm{O}-\mathrm{O}-\mathrm{NH}_{2}$
$\mathrm{Cl}$
Ter $\quad: \mathrm{H}_{2} \mathrm{~N}-\left(\mathrm{O}-\mathrm{O}-\left(\mathrm{O}-\mathrm{NH}_{2}\right.\right.$
PMDA

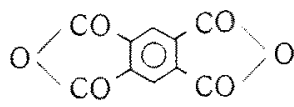
DTDA

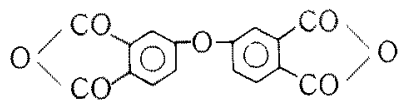
BTDA

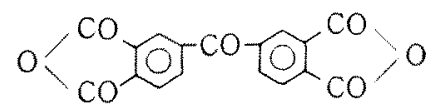
$\mathrm{Cl}$
$\mathrm{AP}-\mathrm{Cl}: \mathrm{H}_{2} \mathrm{~N}-\mathrm{O}-\mathrm{CONH}-\mathrm{O}-\mathrm{NH}_{2}$
$O D$
$: \mathrm{H}_{2} \mathrm{~N}-0-\mathrm{O}-\mathrm{O}-\mathrm{NH}_{2}$

また、ボリーは略号の組合わ世で示した。一例在举

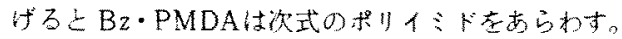

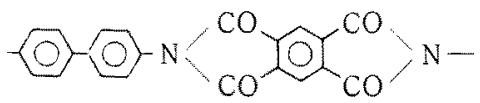

\section{2. 実験方法}

\section{1 藩品類}

2 -クロルーpーフェニレンジアミン $(\mathrm{Cl}-\mathrm{P})$ ：日本化

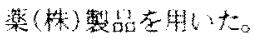

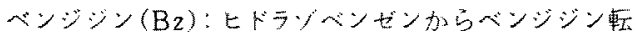
位によって合战した。

2 -クロルベンジジン $(\mathrm{Cl}-\mathrm{B} 2)$ : ニトロソベンゼンと m-クロルアニリンからるークロルアゾベンゼンをつ

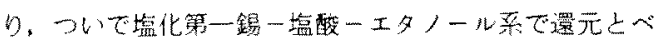
ンジンン軽位を行なて合成しだ。

2,2'-ジクロルベンジジン (Di-Cl-Bz)： $m$-クロル ニトロベンゼンの西鉛末這元で3,3゙ージクロルヒドラゾ ベンゼンをつくり，かでベンジジン転位さ甘て合成し た。

4, 4"ージアミノーpーターフェニル(Ter) : ニトロベン ゼン中， $p$ ターフェニル老発煙硝酸で二ト口化して4,

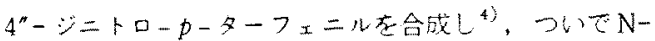
メチルピロリドンを溶媒江用い程化第一錫一塩政系で摆 元して得た。

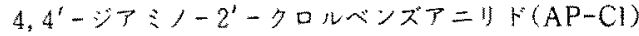
: 2-タロル-4-ニトロアニリンとp-二トロ塩化ベンゾ

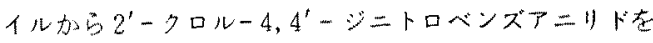
つくり, ついで程化第一錫一塩酸一エタノール䒺で還元 して合成した。 m. p. 202-4 ${ }^{\circ}$ 。

無水ビロメり卜酸(PMDA)：ヒュルス社製品を哭水僧 酸一キシレン搌合溶媒を用にて再結晶精製した。

$3,3^{t}, 4,4^{\prime}$ ージフェニルエーテルテトラカルボン酸二無

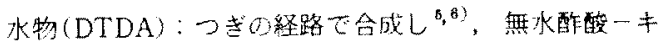
シレン混合溶媒存用いて再結晶精製した。
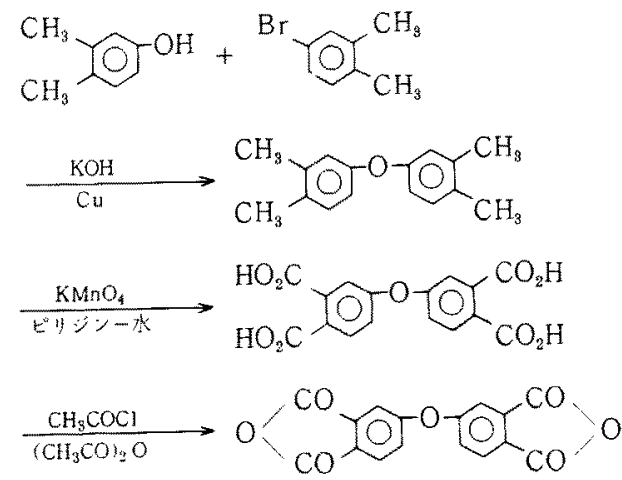
$3,3^{\prime}, 4,4^{\prime}$-ベンゾフェノンテトラカルボン酸二無水物 (BTDA): ガルフ社製品巷無水酢酸を溶媒に用いて再結 晶した。

Nーメチルピロリドン(NMP)：三菱化成(株)製品を モレキュラーシーブて脱水して使用した。

その他の蔝品は試薬品をそのまま用いた。

\section{2 重合方法}

標準的な重合观方孛以下に記す。

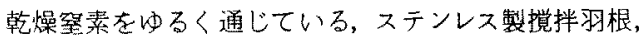
塩化カルシウム管付の $300 \mathrm{ml}$ 四口フラスコにジアミン類 とNMP約 $70 \mathrm{ml}$ 在入れて溶解させ， $20^{\circ} \mathrm{CO}$ 水浴に浸清 L，激しく擋拌しながら粉末状の酸無水物(ジアミンの 1.005 倍モル)を加えた。つで室温で約 5 時間重合を続 けてポリアミド酸溶液を得た。ポリマー漂度は重合開始 時に約 $17 \%$ であり，高粘度の場合はNMPで適宜，希粉 した。

\section{3 ポリアミド酸の溶液中部分锣化}

3.1で後述するように，湿式紡系原液としては 2.2 で 得たポリアミド酸浴液をのままよりも，ポリマー鎖中の アミド酸単值の一部を溶液中で化学的に環化させてイミ ド基に变えたポリマー溶液を用いる万が，ボイドの少な い透明な疑固系を与えることがわか力，通常，との方法 を採用した。以下，その処方を示す。

2. 2 で得たポリアミト酸溶液を水水で泠却し，擋拌下 にアミト酸単位の 0.15〜0.3当量の無水酢酸とピリジン, さらに適当量のNMP加らなる湦合物を約 30 分加けて 滴下し、ついで空温で 4 時間反応を続けた。

\section{4 製系方法}

\subsection{1 湿式紡系}

標集的な紡系条件在以下儿記す。

口金： $0.08 \mathrm{~mm} \phi \times 20$ ホール，吐出量： $0.7 \mathrm{ml} / \mathrm{min}$, 㠜固汾：室温の NMP/水(容積比 25/75)。

紡系速度 $10 \mathrm{~m} / \mathrm{min}$ で替きとり，ついで室温の水中で 延伸した。延伸倍率は 1.3 ～1.5 倍。

\section{4 .2 凝沽系の化学環化}

3.1 で記すように，最終のポリイミド䋐維の引張特性 は，2.4.1で得たポリアミド酸織維を熱㚮理してイミド に環化させるよりも，化学的手段によってあらかじか環 化させ，ついで熱処理する力がはるかに上がりやすく， ほとんどのポリマーでとの方法在採用した。以下，その 好方を示す。

2.4.1で得た凝固糸をガラスボビンに巻いたまま，た だちに室温の無水酢酸/ピリジン(容積比 70/30)に漫漬 し，そのまま一夜放置した。ついで室温のトルエン中に 90 分清的て舆化剂を抽出後, $90^{\circ} \mathrm{C}$ で真空乾燥した。

\subsection{3 熱延伸および燓观理}

公素をゆるく通じた，長さ $30 \mathrm{~cm} の 二$ 重のガラス管 (内管は $5 \mathrm{~mm} \phi$ )を用いて行なった。給系速度は $3 \mathrm{~m} /$ min。

\section{5 測 定}

固有粘度 $\left(\eta_{\mathrm{inh}}\right)$ ：ポリアミド酸の固有粘度は, 重合溶 液をポリマー $0.5 \mathrm{~g} / \mathrm{NMP} 100 \mathrm{ml}$ の割合になるように NMPで希粉し $25^{\circ} \mathrm{C}$ で測定した。ポリイミドの場合は， ポリマー $0.3 \mathrm{~g} /$ 硫酸 $100 \mathrm{ml}$ の濃度に溶解させ, $25 \mathrm{Cで}$ 测定した。

引張特性：東洋ボールドウィン(株)製テンシロンを用 いヤーンについて測定した。試長 $100 \mathrm{~mm}$ ，引張速度 20 $\mathrm{mm} / \mathrm{min}$ 。

密度：四塩化炭素一ヘプタン混合系を用い，浮沈法で $25^{\circ} \mathrm{C}$ で測定した。

$\mathrm{X}$ 線回折：理学電機 (侏) 製X 線発生装置およびゴニオ メーターを使用して測定した。

動的粘弾性：東洋ボールドウィン (株) 製 Rheovibron DDV-I型を用い，振動数 $110 \mathrm{~Hz}$, 昇㵊速度 $3^{\circ} \mathrm{C} / \mathrm{min}$ の条件で測定した。

熱重量分析：島津䌘作所(株)製熱重量分析計 (TG-30 M)を用い，䇪素あるいは空気中，昇温速度 $10^{\circ} \mathrm{C} / \mathrm{min}$ で測定した。

\section{3. 結果と考察}

\subsection{CI-P・PMDA系ポリマーの原液および製 禾条件の検討}

ポリマーの結晶性を適度に低下させる手段として，ま ず核醏素置換をとりあげ，ジアミン成分として Cl-Pを 選び PMDAと重合させてポリアミド酸溶液を得た。こ の重合溶液をそのまま，あるいは2.3亿記した処方でア ミド酸単位の一部を化学的に環化させたポリマー溶液を 紡系原液に用い，NMP一水系凝固浴に湿式紡系し，つ いで熱的あるいは化学的手段によってポリイミドに変換 させた。結果を表1にまとめて記した。

重合したままのポリアミド酸溶液を紡系原液に用いた 場合，数固系はかなり失透した。これに対して，部分環 化ポリマー溶液からの数固系はほ上んど透明であった。 これは表 1 に記した乾燥系の系質にあ反映しており，後 者の方が明らかに強伸度が高い。なお，との部分環化の 凝固系透明化の効果は，溶液中で化学的に環化させる場 合，溶液を保ったままどとまでイミド化可能か調べてい た時，たまたま兒出したるのである。また，2.3で記し た処方で部分環化が確かに起こっていることは以下の2 点から明らかである。ひとつは部分環化ポリマー溶液か ら湿式法で製膜し，室温で真空乾燥したフィルムのIR 
Table 1 Preparation and tensile properties of CIP.PMDA fiber.

\begin{tabular}{|c|c|c|c|c|c|c|c|c|c|c|c|}
\hline \multirow{2}{*}{ Spinning dope } & \multirow{2}{*}{$\eta_{\mathrm{inh}}{ }^{\mathrm{a}}$} & \multirow{2}{*}{$\begin{array}{l}\text { Chemical } \\
\text { imidization } \\
\text { of asspun } \\
\text { fiber }\end{array}$} & \multicolumn{4}{|c|}{ Dried yarn } & \multicolumn{2}{|c|}{$\begin{array}{l}\text { Conditions of } \\
\text { heat-treatment }\end{array}$} & \multicolumn{3}{|c|}{ Heat-treated yarn } \\
\hline & & & Denier & $\begin{array}{c}T \\
(\mathrm{~g} / \mathrm{d})\end{array}$ & $\begin{array}{c}E \\
(\%)\end{array}$ & $\begin{array}{l}M_{\mathrm{i}} \\
(\mathrm{g} / \mathrm{d})\end{array}$ & $\begin{array}{l}\text { Temp. } \\
\text { (C) }\end{array}$ & $\begin{array}{l}\text { Draw } \\
\text { ratio }\end{array}$ & $\begin{array}{c}T \\
(\mathrm{~g} / \mathrm{d})\end{array}$ & $\begin{array}{c}E \\
(\%)\end{array}$ & $\begin{array}{l}\left.M_{\mathrm{i}}{ }^{\mathrm{b}}\right) \\
(\mathrm{g} / \mathrm{d})\end{array}$ \\
\hline \multirow{2}{*}{$\begin{array}{l}\text { Poly (amic-acid) } \\
\text { soln. } \\
\text { (as-polymerized) }\end{array}$} & \multirow[t]{2}{*}{1.26} & & 31 & & 1.1 & 140 & \multicolumn{2}{|c|}{$\begin{array}{l}\text { Heat-treated } \\
\text { stepwise. }\end{array}$} & 25 & 0.5 & \\
\hline & & Yes & 27 & 22 & 0.9 & 270 & 550 & 1.07 & 60 & 0.9 & 720 \\
\hline \multirow{2}{*}{$\begin{array}{l}\text { Partially imidized } \\
\text { polymer soln. }\left(\mathrm{Ac}_{2} \mathrm{O}\right. \\
\text { added : } 30 \text { mole } \%)\end{array}$} & \multirow[t]{2}{*}{1.98} & No & 28 & 1.9 & 2.1 & 130 & \multicolumn{2}{|c|}{$\begin{array}{l}\text { Heat-treated } \\
\text { stepwise. }\end{array}$} & 3.8 & 0.6 & 680 \\
\hline & & Yes & 25 & 24 & 1.0 & 260 & 550 & 1.07 & 8.5 & 1.2 & 800 \\
\hline
\end{tabular}

a) Inherent viscosity $\left(\tau_{i \text { inh }}\right.$ ) was measured at $25^{\circ} \mathrm{C}$ in NMP at a polymer concentration $0.5 \mathrm{~g} / 100 \mathrm{ml}$.

b) $T=$ tenacity, $E$ =elongation, $M_{\mathrm{i}}=$ initial modulus.

These symbols were also used in Tables described later.

c) Heat-treatment was carried out step by step from $200^{\circ} \mathrm{C}$ to $300^{\circ} \mathrm{C}, 400^{\circ} \mathrm{C}$ and $500^{\circ} \mathrm{C}$ at each temperature for 6 seconds.

図に1780,725 $\mathrm{cm}^{-1}$ のイミド基の吸取が楒められたこ とである。すうひとつ估杀秎法の固有粘度が部分環化に よって上舁したてとである(表】参照)。偻者について補 足説明すれば，估有粘度は重合度だけでなくポリマー銷

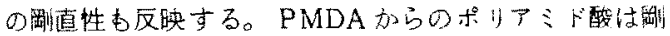
㨁な1,4一アミドと曲力゙った構造の1,3ーアミトがほは 1 対 1 の制合で生成していると思われる(PMDAよメタ

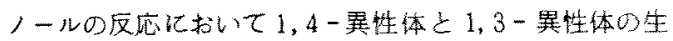

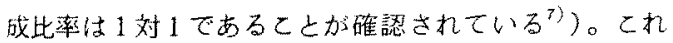
に対してイミドはいずれのアミド酸からら疅化しても棒状 であるから，部分環北に上って重合度は变らなくてあ固 有粘度は当然上界するはずである。

凝固系を2.4.2の処方で化学的に環化させて乾燥した

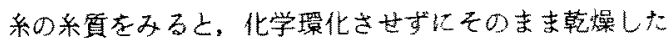

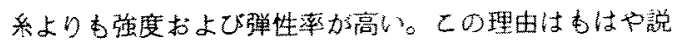
明不要であるう。なお，2.4.2 に記した条件でほぼ完全 に化学環化が進んでいるこしは以下の実甄で確めた。す

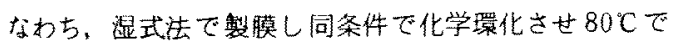
真空乾燥したフィルムのIR函はるのフィルムをさらに $250 \mathrm{C}$ で 1 時間加熱したフィルムのてれとまったく同し であった。このととは娄はや熱的に環化が進む余地がほ とんよ゙ないととを示している。

つき汇熱好理系について述へる。ポリアミド酸䄉維の 熱姏理によるイミド化では，高温で一段好理する姏方は

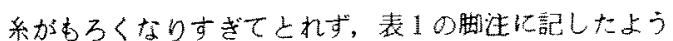

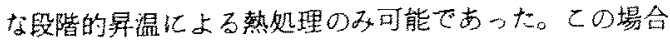

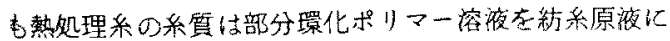
用いる方が重合溶液をたのまま使う場合上り尚加った か，表1から明らかな上うにあらかじか凝固系在化学環 化させ，つにで熱延伸した系の力がらにすぐれていた。 以上の結果から、ポリアミト酸溶液にアミド酸单位の一
部に相当する無水酶酸を加えて部分的にイミド化させ， 湿式紀系後，無水酷酸一ピリジン采に浸漬して残りのア シド酸を化学環化させ，最後化熱延伸する方法加もっ上

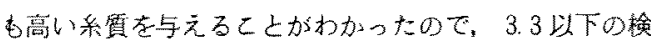

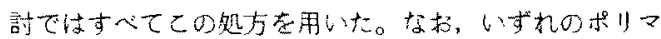
一も湿式製膜法で频固性をチェックしたか，例外なく部 分椱化ポリマー溶夜を用いる方がより透明なフィルムを 与无。

\section{2 禾工程における重合度变化とジアミン成 分の銧長の関俩}

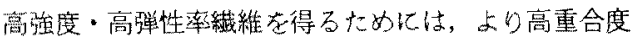

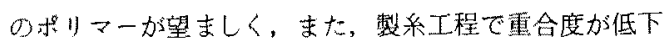
しないポリマーが好ましい。ポリアミド酸は極如て加水

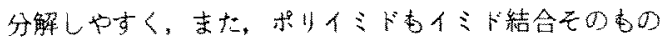

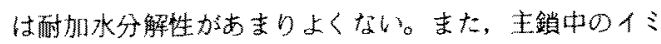
ト基の密度之耐加水分解性の間に関䋆加あることす知ら れている。すなわ占、ジアミン成分がベンゼン環２ケか らなるポリ (4, 4'ーオキシジフニレンピロメリトイミ ト)(OD・PMDA)のフィルムは沸滕水中で 1 年処理して 6タフネス在保つのに効し，バンゼン睘1ケのm-ある いはp-フェニレンジミンのポリピロメリトイミドフ

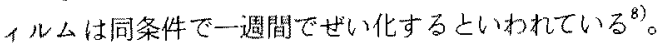

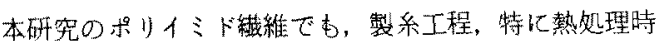
に加水分解汇よる重合度低下が起てっている可能性があ

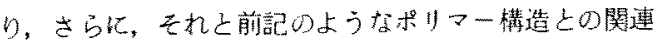
性が予測された。とるか，本研究で取报った，制蕰性 ジアミンのポリピロメリトイミドはいい゙れも硫酸にも溶 解せず，圆有粘度を測れない。をとで，硫酸に溶ける， いいかえれば固有粘度の測定が可能な，ベンゼン置1ケ

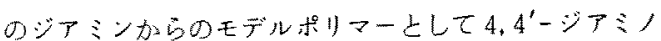
ー2'ークロルベンス゚アーリド( $\mathrm{AP}-\mathrm{Cl})$ のポリピロメリト 
Table 2 Effect of heat-treatment on inherent viscosity of polyimide fibers.

\begin{tabular}{|c|c|c|c|c|}
\hline \multirow[b]{2}{*}{ Polymer } & \multirow[b]{2}{*}{$\begin{array}{l}\eta_{\text {inh of poly- }}{ }^{\text {) }} \\
\text { (amic-acid })\end{array}$} & \multicolumn{3}{|c|}{$\eta_{\text {inh }}$ of polyimide fiber ${ }^{b)}$} \\
\hline & & $\begin{array}{l}\text { Chemically imidized } \\
\text { fiber } \\
\text { (A) }\end{array}$ & $\begin{array}{l}\text { A was heat-treated } \\
\text { at } 250^{\circ} \mathrm{C} \text { in air } \\
\text { for } 1 \mathrm{hr} \text {. }\end{array}$ & $\begin{array}{l}\text { A was heat-treated } \\
\text { at } 450^{\circ} \mathrm{C} \text { in nitrogen } \\
\text { for } 6 \text { seconds. }\end{array}$ \\
\hline $\mathrm{AP}-\mathrm{Cl} \cdot \mathrm{PMDA}$ & 1.72 & 1.82 & 1.32 & 1.13 \\
\hline $\mathrm{OD} \cdot \mathrm{PMDA}$ & 253 & 2.78 & 2.58 & 3.68 \\
\hline
\end{tabular}

Measured at $25^{\circ} \mathrm{C}$ a): in NMP at a polymer concentration $0.5 \mathrm{~g} / 100 \mathrm{ml}$ and b): in $\mathrm{H}_{2} \mathrm{SO}_{4}$ at $0.3 \mathrm{~g} / 100 \mathrm{ml}$.

イミドを選ひ，またバンゼン環 2 ケジアシンからの ポリマーとして, 硫酸に溶けることが知られている前記 のOD・PMDAを用いて製系工程での固有粘度の変化を 追跡した。結果在表 2 に示す。

凝固采の化学環化時に重会度低下が起こっているから゙ うかは, 化学環化の前後でポりマー構造が異なり,さら に粘度測定の溶媒屯違うので，ここでは問わない。問題 代化学環化系の熱処理時の重合度低下であり，表 2 から 明らかなようにベンゼン糫 1 ケのジアミンからのポリイ ミドは予期したと拈り周有粘度が大幅に低下したのに対 し、ベンゼン環 2 ケジアミンからなるOD・PMDA で 敒下の度台汃小さか⿰た。なお，このポリマーで450 ${ }^{\circ} \mathrm{C} ， 6$ 秒の処理により固有粘度が藷しく上界しているの 枯，拓々らくエーテル基の関与する分肢構造の生成のた めであるう！以上の結果から，以後の検討ではベンゼ ン環 2 ケを古つ甽植性ジアミンからのポリマーを主に取 扱うことにした。

\section{3 剛直性ジアミンとPMDAからなるポリイ} ミドの製杀結果

ポリマーの結晶性を適度に低下させる手段として、ジ アミン成分への核塩素置換基の導入，単位長の異なるシ アミンのランダム共重台および両者の併用を試みた。重 台およひ製系結果を表 3 亿一括して記した。なお, 非核 置換のポリマーでは，浚液中の部分環化に使用する無水
酢酸の量が多いと溶液がゲル化するのでアミド酸算位の 15 モル\%に㧕えたが，それであ透明な凝固系が得られ た。また，化学環化糸の熱延伸は大輻に温度を榇えて檢 討したが，表には最高の系質を与える条件を選んで記し to

取报ったいず扎のポリマーあ弾性率は900〜 1000 g /dとほぼ Kevlar - $49^{\circledR}$ (ポリ( $p$ ーフェニレンテレ) タルアミドう了並の水準に達したが, 強度は一般には そ机活じ高くなく，また，予期したような序列であっ

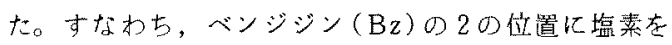
望入するとその数が增すにつれて強度が向上した。一 万，非置換の銧長の異なるジアミンのランダム共重合 体は强度が上がりにくかった。また，塩素置換とラン ダム共重合の雨者老併用した Di-Cl-Bz / P / PMDA (70/30/100)がもっ上も強度が裔く，16 g/d に達し to

\section{$3.4 \mathrm{Bz}$, PMDA およびDTDAあるいはBTDA からなるコポリイミドの製系結果}

緒言でも紹介したように, 制直性ジアミンとDTDAあ るいはBTDAからなるポりイミドは，屈曲する基を含む にかか力らず，比較的高弾性率の䋐維を与えることが知 られている゙,2)。とてでは，ジアミン成尔を $\mathrm{Bz}$ に固定 し，これらのホモポリマ一扰よて第三成分としてPMDA を添加した共重合体について重合および制系を試みた。

Table 3 Hot-drawing conditions and tensile properties of various polypyromellitimide fibers.

\begin{tabular}{|c|c|c|c|c|c|c|c|c|c|c|}
\hline $\begin{array}{c}\text { Diamine } \\
\text { (mole ratio) }\end{array}$ & $\begin{array}{l}\eta_{\text {inh of poly- }} \\
\text { (amic-acid) }\end{array}$ & $\begin{array}{l}\mathrm{Ac}_{2} \mathrm{O} \\
\text { added } \\
(\mathrm{mol} \%)\end{array}$ & $\begin{array}{l}\text { Conditi } \\
\text { hot-dr } \\
\text { Temp. } \\
\text { (C) }\end{array}$ & $\begin{array}{l}\text { ons of } \\
\text { awing } \\
\text { Draw } \\
\text { ratio }\end{array}$ & Denier & $\begin{array}{c}T \\
(\mathrm{~g} / \mathrm{d})\end{array}$ & $\begin{array}{l}E \\
(\mathscr{\%})\end{array}$ & $\begin{array}{c}M_{\mathrm{i}} \\
(\mathrm{g} / \mathrm{d})\end{array}$ & $\begin{array}{l}\text { Density } \\
\left(\mathrm{g} / \mathrm{cm}^{3}\right)\end{array}$ & $\begin{array}{l}\text { Relative } \\
\text { crystallinity }\end{array}$ \\
\hline $\begin{array}{l}\mathrm{Bz} \\
\mathrm{Cl}-\mathrm{Bz} \\
\mathrm{Di}-\mathrm{Cl}-\mathrm{Bz}\end{array}$ & $\begin{array}{l}5.74 \\
3.11 \\
2.45\end{array}$ & $\begin{array}{l}15 \\
20 \\
25\end{array}$ & $\begin{array}{l}575 \\
550 \\
500\end{array}$ & $\begin{array}{l}1.03 \\
1.3 \\
1.3\end{array}$ & $\begin{array}{l}13 \\
32 \\
16\end{array}$ & $\begin{array}{r}7.7 \\
11.1 \\
13.0\end{array}$ & $\begin{array}{l}1.0 \\
1.3 \\
1.6\end{array}$ & $\begin{array}{l}880 \\
980 \\
940\end{array}$ & $\begin{array}{l}1.47 \\
\frac{-}{1.52}\end{array}$ & $\begin{array}{l}1 \\
0.51 \\
0.18\end{array}$ \\
\hline $\begin{array}{l}\mathrm{P} / \mathrm{Bz}(60 / 40) \\
\mathrm{Bz} / \mathrm{Ter}(55 / 45)\end{array}$ & $\begin{array}{l}3.85 \\
2.19\end{array}$ & $\begin{array}{l}25 \\
15\end{array}$ & $\begin{array}{l}575 \\
600\end{array}$ & $\begin{array}{l}1.1 \\
1.1\end{array}$ & $\begin{array}{r}9 \\
25\end{array}$ & $\begin{array}{l}11.0 \\
10.3\end{array}$ & $\begin{array}{l}1.2 \\
1.3\end{array}$ & $\begin{array}{r}1030 \\
940\end{array}$ & & \\
\hline $\begin{array}{l}\mathrm{Di}-\mathrm{Cl}-\mathrm{Bz} / \mathrm{P} \\
(70 / 30)\end{array}$ & 2.22 & 25 & $\begin{array}{l}550 \\
585\end{array}$ & $\begin{array}{l}1.3 \\
1.3\end{array}$ & $\begin{array}{l}27 \\
28\end{array}$ & $\begin{array}{l}14.8 \\
16.3\end{array}$ & $\begin{array}{l}1.7 \\
2.0\end{array}$ & $\begin{array}{r}1030 \\
960\end{array}$ & & \\
\hline
\end{tabular}

a) Partial imidization in soln.

b) Ratio of maximum peak height of equatorial scattering. 
Table 4 Hot-drawing conditions and tensile properties of Bz/PMDA/DTDA and $\mathrm{Bz} / \mathrm{PMDA} / \mathrm{BTDA}$ copolyimide fibers.

\begin{tabular}{|c|c|c|c|c|c|c|c|c|c|}
\hline $\begin{array}{l}\text { Dianhydride } \\
\text { (mole ratio) }\end{array}$ & $\begin{array}{l}\eta_{\text {inh }} \text { of poly- } \\
\text { (amic-acid) }\end{array}$ & $\begin{array}{c}\mathrm{Ac}_{2} \mathrm{O} \text { added }{ }^{\mathrm{a})} \\
(\text { mole } \%)\end{array}$ & $\begin{array}{l}\text { Conditior } \\
\text { drawing } \\
\text { Temp. }(\mathrm{C})\end{array}$ & $\begin{array}{l}\text { ns of hot- } \\
\text { Draw ratio }\end{array}$ & Denier & $\begin{array}{c}T \\
(\mathrm{~g} / \mathrm{d})\end{array}$ & $\begin{array}{c}E \\
(\%)\end{array}$ & $\begin{array}{c}M_{\mathrm{i}} \\
(\mathrm{g} / \mathrm{d})\end{array}$ & $\begin{array}{l}\text { Density } \\
\left(\mathrm{g} / \mathrm{cm}^{3}\right)\end{array}$ \\
\hline $\begin{array}{c}\text { PMDA/ DTDA } \\
100 / 0 \\
70 / 30 \\
50 / 50 \\
40 / 60 \\
35 / 65 \\
25 / 75 \\
0 / 100\end{array}$ & $\begin{array}{l}5.74 \\
4.09 \\
2.51 \\
2.38 \\
2.33 \\
1.46 \\
1.70 \\
\end{array}$ & $\begin{array}{l}15 \\
15 \\
15 \\
20 \\
20 \\
25 \\
15 \\
\end{array}$ & $\begin{array}{l}575 \\
600 \\
600 \\
550 \\
550 \\
425 \\
600\end{array}$ & $\begin{array}{l}1.03 \\
2.0 \\
3.5 \\
6.5 \\
6.5 \\
5.9 \\
3.0\end{array}$ & $\begin{array}{r}13 \\
20 \\
14 \\
7 \\
8 \\
9 \\
18 \\
\end{array}$ & $\begin{array}{r}7.7 \\
12.0 \\
15.3 \\
19.7 \\
18.5 \\
9.4 \\
10.7\end{array}$ & $\begin{array}{l}1.0 \\
1.4 \\
1.6 \\
1.7 \\
1.6 \\
1.1 \\
1.8\end{array}$ & $\begin{array}{r}880 \\
1010 \\
1160 \\
1310 \\
1250 \\
880 \\
710\end{array}$ & $\begin{array}{c}1.47 \\
- \\
- \\
1.44 \\
- \\
\overline{1.44}\end{array}$ \\
\hline $\begin{array}{c}\text { PMDA/ BTDA } \\
50 / 50 \\
0 / 100\end{array}$ & $\begin{array}{l}2.38 \\
1.58\end{array}$ & $\begin{array}{l}15 \\
15\end{array}$ & $\begin{array}{l}600 \\
575\end{array}$ & $\begin{array}{l}1.8 \\
1.5\end{array}$ & $\begin{array}{l}16 \\
43\end{array}$ & $\begin{array}{l}9.4 \\
6.3\end{array}$ & $\begin{array}{l}1.2 \\
1.1\end{array}$ & $\begin{array}{l}940 \\
650\end{array}$ & \\
\hline
\end{tabular}

a) Partial imidization in soln.

結果を表4に示した。ポリアミド酸の固有粘度は一般に DTDA 成分の多いは上゙低い。こ机は重合度も低いので あろうが，ポリマー構造屯反映していると思われる。す な⿰七，3.1で述心゙たようにPMDAからのポリアミド 酸はその半分が剛直な 1,4 -アミドでありDTDA からの それよりも浴波中でポリマー銷が広加りやすいからであ る。 Bz・DTDAのホモポリイミドは延伸性がよく，確 加汃り高強度・高弾性率の瀻維を与えたが, 表加ら わ加るように，そ扎化PMDAを添加した三成分采共重 合体加ら,さらに高性能の繊維が得られた。そして, PMDA/DTDA (40/60)に系質のピークがあり，ほほ $20 \mathrm{~g} / \mathrm{d}$ の強度と $1310 \mathrm{~g} / \mathrm{d}$ の高弾性率加達成された。 この組成の共重合体で強度は上も汃く弾性率がもっとも 高いのは予想外であった。なぜならホホリマー構造から いえば，PMDA成分の多いはど素質的にはより高弾性 率のはずだからである。結局, 我々の用いた製系法では PMDA 成分の多い，上り高結晶性のポリマーからはそ の潜在性能を十分に引出すとよができなかったためであ ろう。

BTDA采ポリマーは，木モポリマー季PMDAを添加 した共重合体のいずれも延神性が DTDA采より劣り,
系質も呧かった。な拉，筆者らは以前，アラミド系共重 合体で同様な現象，すな⿰力口，共重合成分中に導入する 届曲基がエーテルの場台，ケトンよりも延伸性，ひいて は糸質が高いと袁認めている ${ }^{10 \%} 。$

\section{5 酸無水物成分がPMDA/DTDA $(70 / 30)$ か} らなるコポリイミドの製米結果

酸無水物成分を， $\mathrm{Bz} / \mathrm{PMDA} / \mathrm{DTDA}$ 系で最高の采 質を与えた組成よりも剈直性の高いPMDA/DTDA(70 /30）に固定し，か打りにジアミン成分老核塩素置換あ るいは単位長の異なるモ/マーのランダム共重合によっ て構造を乱した其重合体について重合および製系を試み た。結果を表 5 にまとめた。との場合も，非核置換ジア ミンのランダム共重合より核塩素置換の方が強度向上に は効果があり，前駆重合体であるポリアミド酸の固有粘 度がかなり低いに出か加わらず，17〜18 g/d の高強度 繊維少得られた。なお，弾性率はどの共重合体もは $1000 \mathrm{~g} / \mathrm{d}$ 古るいはそれ以上であったが，3.4亿記した B2/PMDA/DTDA(100/40/60)のそれには及ばなか力 sた。

\section{6 各種ポリイミド緟維のX線回折}

主なホモポリイミド織維 5 種のX線回折を測定した。

Table 5 Hot-drawing conditions and tensile properties of random copolyimide fibers comprising PMDA/DTDA (70/30) as dianhydride components.

\begin{tabular}{|c|c|c|c|c|c|c|c|c|}
\hline $\begin{array}{c}\text { Diamine } \\
\text { (mole ratio) }\end{array}$ & $\begin{array}{l}\eta_{\text {inh }} \text { of poly- } \\
\text { (amic-acid) }\end{array}$ & $\begin{array}{l}\mathrm{Ac}_{2} \mathrm{O} \text { added }^{\mathrm{a})} \\
(\text { mole } \not \%)\end{array}$ & $\begin{array}{l}\text { Condition } \\
\text { drawing } \\
\text { Temp. ('C) } \\
\end{array}$ & $\begin{array}{l}\text { s of hot- } \\
\text { Draw ratio }\end{array}$ & Denier & $\begin{array}{c}T \\
(\mathrm{~g} / \mathrm{d})\end{array}$ & $\begin{array}{c}E \\
(\%)\end{array}$ & $\begin{array}{c}M_{\mathrm{i}} \\
(\mathrm{g} / \mathrm{d})\end{array}$ \\
\hline $\begin{array}{l}\mathrm{Di}-\mathrm{Cl}-\mathrm{B} z / \mathrm{Bz}(70 / 30) \\
\mathrm{Cl}-\mathrm{Bz}\end{array}$ & $\begin{array}{l}1.41 \\
1.71 \\
\end{array}$ & $\begin{array}{l}25 \\
20 \\
\end{array}$ & $\begin{array}{l}575 \\
550 \\
\end{array}$ & $\begin{array}{r}5.2 \\
4.2 \\
\end{array}$ & $\begin{array}{l}13 \\
17 \\
\end{array}$ & $\begin{array}{l}18.0 \\
17.0 \\
\end{array}$ & $\begin{array}{l}2.1 \\
1.9 \\
\end{array}$ & $\begin{array}{r}990 \\
1070 \\
\end{array}$ \\
\hline $\begin{array}{l}\mathrm{B} z / \mathrm{P}(70 / 30) \\
\mathrm{B} z / \operatorname{Ter}(60 / 40)\end{array}$ & $\begin{array}{l}3.64 \\
3.28\end{array}$ & $\begin{array}{l}15 \\
15\end{array}$ & $\begin{array}{l}575 \\
550\end{array}$ & $\begin{array}{l}2.6 \\
2.8\end{array}$ & $\begin{array}{l}13 \\
11\end{array}$ & $\begin{array}{l}13.9 \\
15.3 \\
\end{array}$ & $\begin{array}{l}1.6 \\
1.4 \\
\end{array}$ & $\begin{array}{l}1040 \\
1180\end{array}$ \\
\hline
\end{tabular}

a) Partial imidization in soln. 

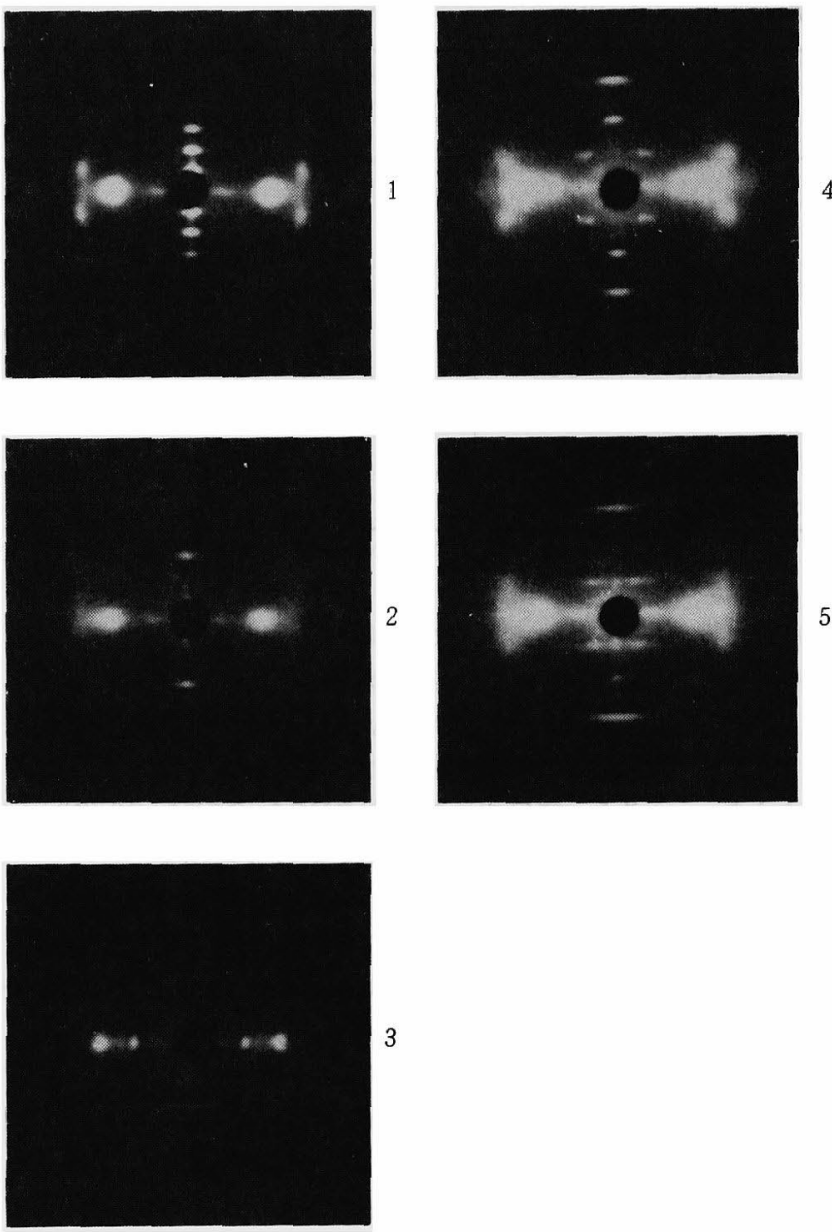

Fig. 1 X-ray diffraction patterns of polyimide fibers.

1: $\mathrm{Bz} \cdot \mathrm{PMDA}, \quad 2: \mathrm{Cl}-\mathrm{Bz} \cdot \mathrm{PMDA}$, 3: Di-Cl-Bz.PMDA, 4: Bz.DTDA, 5: Bz.BTDA
広角プレート写真を図 1 に, また, 子午 線干涉の面間隔およびそれから算出した 綫維周期を表 6 に記した。図 1 からいず れあよく配向した結晶性繊維であると認 められるが, $\mathrm{Bz} \cdot \mathrm{PMDA}$ 系ポリマーで は $\mathrm{B} z$ に核塩素置換する之その数が增す につれて結晶性が低下しているととがわ かる。また，その繊維周期は核塩素置換 の有無にかかわらず16.5〜 16.6 ̊であり， 繰返し単位長とほぼ同じである。 $\mathrm{Bz}$. DTDA および Bz・BTDA各ホモポリマ 一屯高結晶性であり, 繊維周期は下記の 伸びきった構造（I）の単位長にほぼ相当 し，とりうる立体配置によってはポリマ 一鎖が剛直になることを襄付けている。<smiles></smiles>

(X：OまたはCO)

\section{7 各種ポリイミド繊維の動的} 粘弾性

主なポリイミド繊維の動的粘弾性を測 定した。図 2 亿損失正接 $(\tan \delta)$ の温度 プロフィルを, また, 表 7 亿眝蔵弾性率 $\left(E^{\prime}\right)$ の高温時の保持率を示した。当然 のととながら, Bz・PMDAホモポリマー は分散が小さく, 高温時の $E^{\prime}$ 保持率が高 い。乙れに対して, $\mathrm{Di}-\mathrm{Cl}-\mathrm{Bz} \cdot \mathrm{PMDA}$ は $190^{\circ} \mathrm{C}$ 付近にかなり大きな分散があり， 高温時の $E^{\prime}$ 保持率は低い。また, $\mathrm{Cl}-\mathrm{Bz}$

・PMDAは両者の中間である。これらの

Table 6 d-Spacings of meridional scattering and fiber identity periods of polyimide fibers.

\begin{tabular}{|c|c|c|c|c|c|}
\hline & $\mathrm{Bz} \cdot \mathrm{PMDA}$ & $\mathrm{Cl}-\mathrm{Bz} \cdot \mathrm{PMDA}$ & $\mathrm{Di}-\mathrm{Cl}-\mathrm{Bz} \cdot \mathrm{PMDA}$ & $\mathrm{Bz} \cdot \mathrm{DTDA}$ & $\mathrm{Bz} \cdot \mathrm{BTDA}$ \\
\hline $\begin{array}{c}\mathrm{d}-\text { Spacing } \\
\text { (§) }\end{array}$ & $\begin{array}{l}8.35(\mathrm{~s}) \\
5.54(\mathrm{~s}) \\
4.15(\mathrm{~s}) \\
3.33(\mathrm{~s}) \\
2.76(\mathrm{~s}) \\
2.37(\mathrm{~m}) \\
2.08(\mathrm{~s})\end{array}$ & $\begin{array}{l}5.54(\mathrm{~s}) \\
4.11(\mathrm{~m}) \\
3.30(\mathrm{~m}) \\
2.74(\mathrm{w}) \\
2.36(\mathrm{w}) \\
2.07(\mathrm{~s})\end{array}$ & $\begin{array}{l}5.54(w) \\
3.33(w) \\
2.76(\mathrm{~m}) \\
2.37(w) \\
2.08(w)\end{array}$ & $\begin{array}{l}5.31(w) \\
3.51(w) \\
2.66(w) \\
\\
2.13(\mathrm{~s}) \\
1.94(w)\end{array}$ & $\begin{array}{l}5.44(\mathrm{~s}) \\
4.38(w) \\
3.59(w) \\
2.70(\mathrm{~s}) \\
2.39(w) \\
2.15(w) \\
1.96(w)\end{array}$ \\
\hline $\begin{array}{l}\text { Fiber identity } \\
\text { period }(\AA)\end{array}$ & 16.6 & 16.5 & 16.6 & 21.2 & 21.6 \\
\hline
\end{tabular}

$\mathrm{s}$ : strong, m: medium, w: weak 


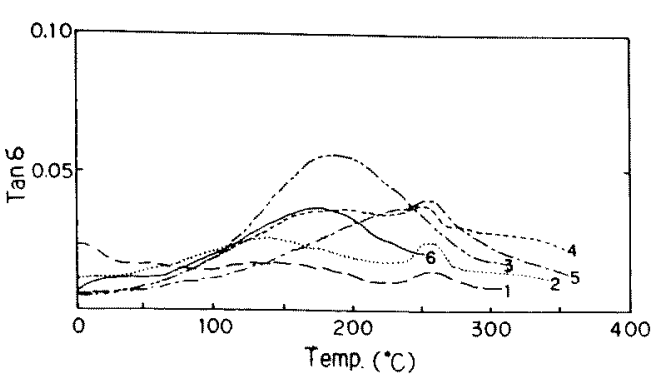

Fig. 2 Temperature dependence of $\tan \delta$ for polyimide fibers.

1: $\mathrm{Bz} \cdot \mathrm{PMDA}, \quad 2: \mathrm{Cl}-\mathrm{Bz} \cdot \mathrm{PMDA}$,

3: Di-Cl-Bz.PMDA, 4: Bz.DTDA,

5: Bz.BTDA, 6: Bz/PMDA/DTDA

$(100 / 40 / 60)$

Table 7 Percentage (\%) of storage modulus $\left(E^{\prime}\right)$ retained at elevated temperature for polyimide fibers.

\begin{tabular}{l|ccc}
\hline $\begin{array}{c}\text { Polymer } \\
\text { (mole ratio) }\end{array}$ & $100^{\circ} \mathrm{C}$ & $200^{\circ} \mathrm{C}$ & $300^{\circ} \mathrm{C}$ \\
\hline $\mathrm{B} z \cdot \mathrm{PMDA}$ & 93 & 81 & 77 \\
$\mathrm{C} 1-\mathrm{Bz} \cdot \mathrm{PMDA}$ & 95 & 74 & 63 \\
$\mathrm{Di}-\mathrm{C} 1-\mathrm{Bz} \cdot \mathrm{PMDA}$ & 91 & 63 & 43 \\
$\mathrm{Bz} \cdot \mathrm{DTDA}$ & 92 & 72 & 54 \\
$\mathrm{Bz} \cdot \mathrm{BTDA}$ & 86 & 73 & 55 \\
$\mathrm{~B} 2 / \mathrm{PMDA} / \mathrm{DTDA}$ & 92 & 75 & - \\
$(100 / 40 / 60)$ & & & \\
cf. & 89 & 81 & 68 \\
Kevlar-49 & & & \\
\hline
\end{tabular}

データは3.6で記した結昆性の程度とよく対応している。 一方，Bz・DTDAおよび Bz・BTDA各ホモポリマーは 200〜250Сにやや大きい分散があり，これに相応して $300 \mathrm{C}$ の $E^{\prime}$ 保持率がかなり低い。Bz/PMDA/DTDA

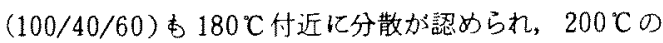
$E^{\prime}$ 保持率はやや低い。表 7 亿は Kevlar $-49^{\circledR}$ の $E^{\prime}$ 保持 率も合わせて記したが，乙れと比較して $E^{\prime}$ 保持率が同等 かそれ以上であるのは $\mathrm{B} 2 \cdot \mathrm{PMDA}$ ホモポリマーのみで あり，他のポリマーはいずれも劣っている。

\section{8 各種ポリイミド溨維の熱重量分析}

主なホモポリイミト稚維 5 種の熱重量分析を武みた。
Table 8 Thermogravimetric analysis of polyimide fibers.

\begin{tabular}{|c|c|c|}
\hline \multirow[t]{2}{*}{ Polymer } & \multicolumn{2}{|c|}{$\begin{array}{l}\text { Temp. (C) at which } 5 \% \text { wt. } \\
\text { loss occurred }\end{array}$} \\
\hline & in nitrogen & in air \\
\hline $\mathrm{Bz} \cdot \mathrm{PMDA}$ & 580 & 490 \\
\hline $\mathrm{Cl}-\mathrm{B} 2 \cdot \mathrm{PMDA}$ & 588 & 525 \\
\hline $\mathrm{Di}-\mathrm{Cl}-\mathrm{Bz} \cdot \mathrm{PMDA}$ & 550 & 524 \\
\hline $\mathrm{Bz} \cdot \mathrm{DTDA}$ & 600 & 518 \\
\hline $\mathrm{Bz} \cdot \mathrm{BTDA}$ & 590 & 545 \\
\hline
\end{tabular}

a) Heating rate: $10^{\circ} \mathrm{C} / \mathrm{min}$.

結果を表 8 にまぬた。表加ら，いずれのポリマーもと の方法で評洒した耐熱性は極めて高いととがわかる。

付記：この研究は，通商産業省工業技術院の次世代産 業基盤技術研究開発制度に基づき高分子基盤技術研究組 合肪委託を受けた高結晶性高分子材料の研究開発の一つ として行なわれたものである。

\section{文献}

1) M. M. Koton, Polym. Sci. USSR, 21, 2756 (1980)

2) インスティチュト・ヴィソコモレクリヤルニヒ・ソ エゴィネニイ・アカデミイ・ナワク・エスエスエス エル; 特公昭 57-37687

3) J. Burns, H. McCombie, H. A. Scarborough, J. Chem. Soc., 1928, 2928

4) J. A. Vanallan, J. Org. Chem., 21, 1152 (1956)

5) C. S. Marvel, J. H. Rassweiter, J. Am. Chem. Soc., 80, 1197 (1958)

6) G. S. Kolesnikov, O. Ya. Fedotova, E. I. Hofbauer, V. G. Shelgayeva, Polym. Sci. USSR, 9, 685 (1967)

7）西崎俊一郎，森脇紀元，工化誌，71，1559(1968)

8) C. E. Sroog, A. L. Endrey, S. V. Abramo, C. E. Berr, W. M. Edwards, K. L. Olivier, J. Polym. Sci., A3, 1373 (1965)

9) R. S. Irwin, W. Sweeny, J. Polym. Sci., C19, 41 (1967)

10) 神田坧馬, 河合 孝, 瀻学誌, 37, T-279(1981) 